\title{
Revealing Seed Coat Colour Variation and Their Possible Association with Seed Yield Parameters in Common Vetch (Vicia sativa L.)
}

\author{
Gulgun Yildiz Tiryaki, ${ }^{1}$ Abdullah Cil, ${ }^{2}$ and Iskender Tiryaki ${ }^{3}$ \\ ${ }^{1}$ Department of Food Engineering, Faculty of Engineering, Canakkale Onsekiz Mart University, 17100 Canakkale, Turkey \\ ${ }^{2}$ East Mediterranean Agriculture Research Institute, Yuregir, Adana, Turkey \\ ${ }^{3}$ Department of Agricultural Biotechnology, Faculty of Agriculture, Canakkale Onsekiz Mart University, 17100 Canakkale, Turkey
}

Correspondence should be addressed to Iskender Tiryaki; itiryaki@comu.edu.tr

Received 28 July 2016; Accepted 3 November 2016

Academic Editor: Manuel Tejada

Copyright (C) 2016 Gulgun Yildiz Tiryaki et al. This is an open access article distributed under the Creative Commons Attribution License, which permits unrestricted use, distribution, and reproduction in any medium, provided the original work is properly cited.

\begin{abstract}
The seed coat colour variation of 70 common vetch genotypes were determined by using uniform colour scale $\left(L^{*} a^{*} b^{*}\right)$ and their possible correlation with seed yield parameters including the number of pods per plant, the number of seeds per pod, pod dimension, and seed yield $(\mathrm{kg} / \mathrm{da})$ was determined. The results revealed presence of highly significant $(p<0.01)$ variations for both the seed yield and the seed coat colour parameters measured. The number of pods per plant, the number of seeds per pod, and seed yield ranged from 5.8 to 16.03, from 5.2 to 7.66, and from 143.37 to 531.1, respectively. The lightness value varied from 19.00 to 40.28 while chromaticity $a^{*}$ and $b^{*}$ values ranged from -0.16 to 8.99 and from 0.79 to 22.11 , respectively. The highest correlation coefficients were determined between $b^{*}$ and $L^{*}(r=0.73)$, and $a^{*}$ and $L^{*}(r=0.55)$. The seed coat colour traits and seed yield parameters generally showed weak negative correlations. Seed yellowness $\left(b^{*}\right)$ and seed yield had correlation coefficient of -0.25 , while correlation between $L^{*}$ and seed yield was determined as -0.23 . The results indicated that lightness and yellowness of seed coat may be used as an important parameter to prescreen high yield genotypes of common vetch.
\end{abstract}

\section{Introduction}

The genus Vicia is very important not only for providing low cost animal forage and grain species of food but also for their contribution to organic biomass and nitrogen to soil in a plant rotation system $[1,2]$. Vicia species is widespread especially in the temperate zones of both hemispheres $[3,4]$ and the center of diversity for subgenus Vicia is shown as the Northeastern Mediterranean, including Iraq, Iran, the Southwestern Republics of the former Soviet Union, Syria, and Turkey [5]. Annual common vetch (Vicia sativa ssp. sativa) is one of the most genetically and phenotypically variable species of Vicia and has ability to grow over a wide range of climatic and soil conditions [6]. Although such genetic variation was also visually available for seed coat colour of Vicia sativa ssp. sativa, quantification was not previously determined with high accuracy. One strategy for trying to accurately measure and understand this continuous colour variation is to use reflectance spectra [7] which allows determination of colours $L^{*}, a^{*}$, and $b^{*}$ values obtained from optical instruments based on the International Commission on Illumination (CIE) numerical system, which evaluates the colour of samples in three axes $L-a-b$. Axis $L^{*}$ defines the lightness of the sample expressed in ranges from 0 (black) to 100 (white), while the perpendicular axes $\left(a^{*}\right.$ and $\left.b^{*}\right)$ characterize the shades in pairs of colours [8]. Chromaticity $a^{*}$ ranges from -60 (green) to +60 (red), while chromaticity $b^{*}$ ranges from -60 (blue) to +60 (yellow) [8].

The seed coat, a main modulator of interactions between the internal structures of the seed and the external environment, not only preserves integrity of the seed parts but also protects the embryo from mechanical injures and attacks of pest diseases. The seed coat also improves the survival of seeds in the soil especially in adverse environmental 
conditions and helps to avoid extinction of species in nature $[9,10]$. Seed coat attains their specific colour at physiological maturity and seed coat pigmentation has been shown to play an important role in seed dormancy and germination [11-13]. It was reported that seed size and coat colour are important characteristics for distinguishing between hardseeded and soft-seeded varieties of Vicia sativa, while the seed size of hard-seeded lines is smaller than that of the soft-seeded lines [14]. In addition, seed size and seed coat colour have been used to develop a convenient method of seed quality improvement for several crop species including common bean [8, 15], cowpea [16], rapeseed [17], flax [18], and Arabidopsis [11]. The aims of this study were to determine seed coat colour variation and their possible correlation with seed yield parameters in common vetch lines and cultivars.

\section{Materials and Methods}

2.1. Materials. A total of 70 common vetch lines and cultivars (62 lines and 8 cultivars) were used in this study (Table 1). Seed material was either obtained from national or international genetic resources or collected from natural flora of Turkey (Table 1). Seeds of individual plants of natural flora collected at locations shown in Table 1 were grown and were selfed to propagate enough seeds under the same field conditions for 2 years. Those seeds were reconfirmed to assure the correct taxonomic classification ( $V$. sativa ssp. sativa) and no intrapopulation diversity was detected.

2.2. Planting and Field Conditions. Field study was conducted at East Mediterranean Transitional Zone Agricultural Research Institute, Kahramanmaras, Turkey, in 2008-2009 growing season. Altitude was 474 meters, and latitude and longitude were $37^{\circ} 38^{\prime}$ North and $36^{\circ} 37^{\prime}$ East, respectively. Average annual minimum and maximum temperatures were 4.5 and $26.3^{\circ} \mathrm{C}$, with an average of $12.8^{\circ} \mathrm{C}$ during growing season, from November 2008 to June 2009, respectively. The experiment soil is classified as a loam soil and a $\mathrm{pH}$ of 7.55 $\left(\mathrm{CaCO}_{3}\right.$ of $26.92 \% ; \mathrm{P}_{2} \mathrm{O}_{5}$ of $0.48 \mathrm{~kg} / \mathrm{ha} ; \mathrm{K}_{2} \mathrm{O}$ of $0.41 \mathrm{~kg} / \mathrm{ha}$; and $1.85 \%$ organic matter) and mean annual precipitation have been reported as $818.4 \mathrm{~mm}$ during the growing season. A randomized complete block design was used for field experiment with 3 replications. Four rows of seeds with $4 \mathrm{~m}$ long and $30 \mathrm{~cm}$ apart $\left(3.6 \mathrm{~m}^{2}\right)$ were planted with a seed planter at $3 \mathrm{~cm}$ depth. A mechanical weed control was made as needed and neither fertilizer nor pesticide was applied.

Pods of 10 randomly chosen plants reached to full maturity stages in the middle two rows of each plot that were used to determine the number of pods per plant, the number of seeds per pod, pod dimension, and seed yield $(\mathrm{kg} / \mathrm{da})$ when the plants reached at full pod maturity stage for each genotype. Pod dimension (widths and lengths) (mm) was measured by using Vernier. The number of pods per plant, the number of seeds per pod, and seed yield $(\mathrm{kg} / \mathrm{da})$ parameters were determined as described previously [19].

2.3. Seed Coat Colour Determination. The seeds harvested from the same field experiment were stored at the same room conditions and were used for colour determination. The following colour traits were measured by Minolta instrument (CR 300) based on the International Commission on Illumination (CIE) colour solid scale $\left(L^{*}, a^{*}, b^{*}\right)$ : lightness (from black $=0$ to white $=100), a^{*}$ (red-purple $=$ positive value and green-bluish $=$ negative value $), b^{*}$ (yellow $=$ positive value and blue $=$ negative value $)$, and $a / b$ ratios for each line and cultivar with three replications. Instrument was recalibrated after each five measurements.

2.4. Statistical Analysis. Data were subjected to analysis of variance using SAS [20], and the mean separation was performed by Tukey's Studentized Range (HSD) test, if the $F$-test was significant at $p<0.05$. Pearson's correlation coefficient was used to assess the correlations among the seed coat colour and seed yield parameters.

\section{Results}

3.1. Seed Yield and Yield Components. The results revealed significant $(p<0.01)$ variations for the seed yield and the seed coat colour parameters measured (Table 1). The highest number of pods per plant was determined as 16.03 from the line encoded as GB-6, while the line TA- 8 had the lowest (5.80). The line IC-13 had the lowest number of seeds per pod (5.20), while the line GB- 8 gave the highest (7.66). The wideness $(7.93 \mathrm{~mm})$ and longness $(61.30 \mathrm{~mm})$ of pods were the highest for the line IC-15, while the lines GB-6 and TA18 had narrowest $(5.76 \mathrm{~mm})$ and shortest $(41.63 \mathrm{~mm})$ pods. The common vetch lines and cultivars varied 3.7-fold (143.37 to $531.10 \mathrm{~kg} / \mathrm{da}$ ) for seed yield. The lowest seed yield was obtained from the line encoded as DV-1, while the line CU-2 had the highest seed yield.

Average minimum and maximum numbers of pods per plant were 3.9 and 16.6 , with an average of 9.56 pods, while minimum and maximum numbers of seeds per pod were 4.0 and 8.8 , with an average of 6.48 seeds (Table 2 ). Average pod width and length were determined as $6.75 \mathrm{~mm}$ and $50.64 \mathrm{~mm}$, respectively. Average minimum and maximum seed yields were $36.70 \mathrm{~kg} / \mathrm{da}$ and $676.70 \mathrm{~kg} / \mathrm{da}$, with an average of 322.55 seed $\mathrm{kg} / \mathrm{da}$ (Table 2).

3.2. Seed Coat Colour Parameters. Digital measurements of seed coat colour of 62 lines and 8 cultivars showed significant $(p<0.01)$ differences for all colour traits measured (Table 1). The seed coat colour of cultivar Karaelci (CE-6) had the lowest $L^{*}, a^{*}, b^{*}$, and $a / b$ values which were determined as $19.00,-0.16,0.79$ and -1.02 , respectively. The cultivar Nilufer (CE-8) provided the highest values of lightness $\left(L^{*}\right.$, $40.28)$ and yellowness $\left(b^{*}, 22.11\right)$, while green-bluish value $\left(a^{*}\right)$ was the lowest $(-0.16)$ for cultivar Karaelci. The redpurpleness $\left(a^{*}\right)$ and red-purpleness/yellowness ratios $(a / b)$ were the highest (8.99 and 1.37) for the lines GB-20 and TA17 , respectively (Figure 1 ).

Average minimum and maximum numbers of $L^{*}, a^{*}, b^{*}$, and $a / b$ values for 62 lines and 8 cultivars were 18.73 and 41.57, -0.32 and 29.66, 0.11 and 23.60, and -2.91 and 3.15, respectively (Table 2 ). An average $L^{*}, a^{*}, b^{*}$, and $a / b$ values 


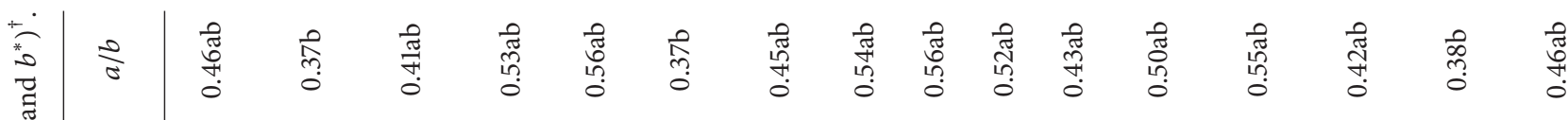

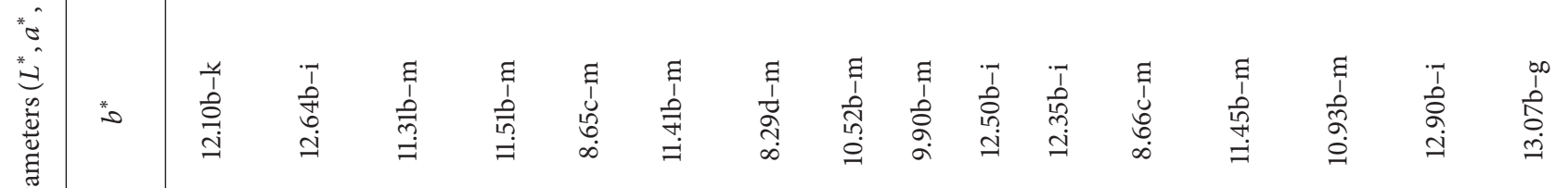

है

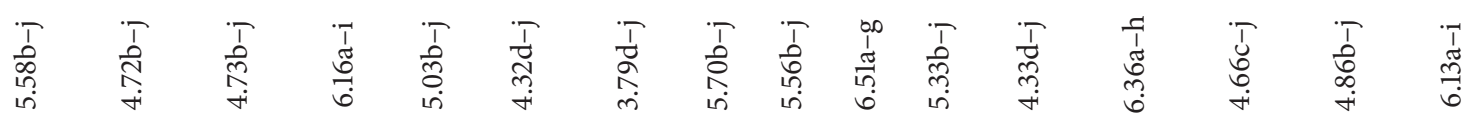

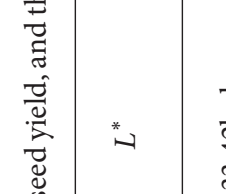

居

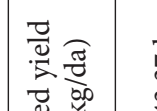

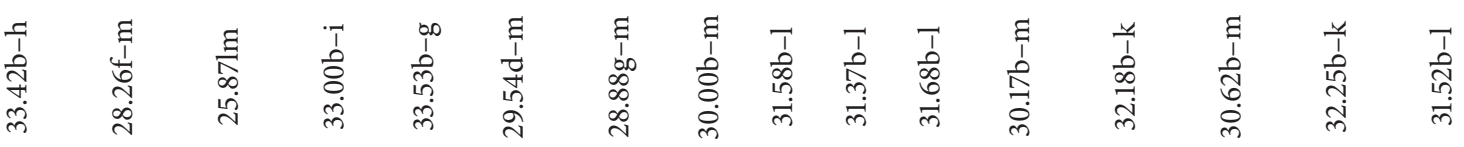

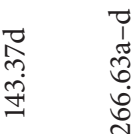

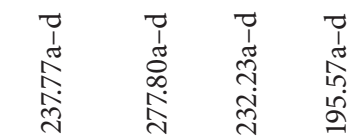

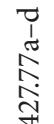

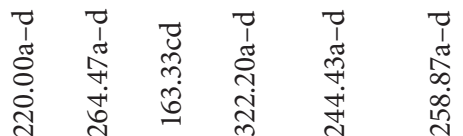

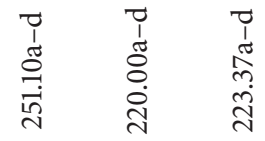

क्ञ

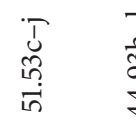

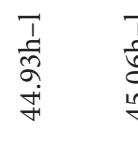

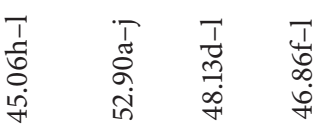

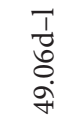

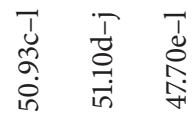

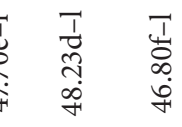

$\mathfrak{u}$
$\stackrel{0}{0}$
in

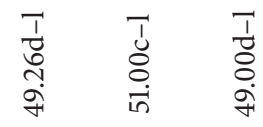

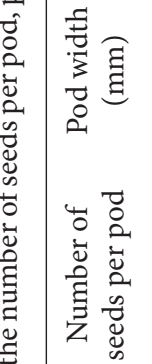

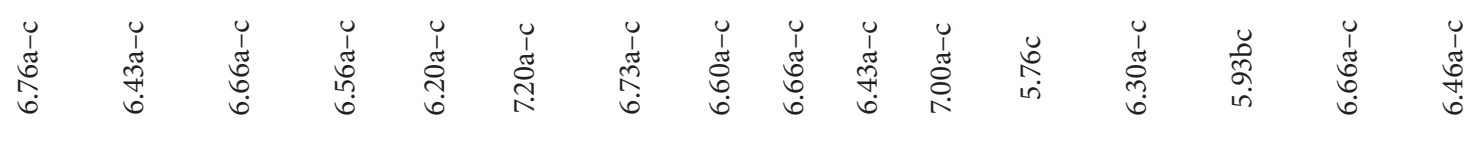

范

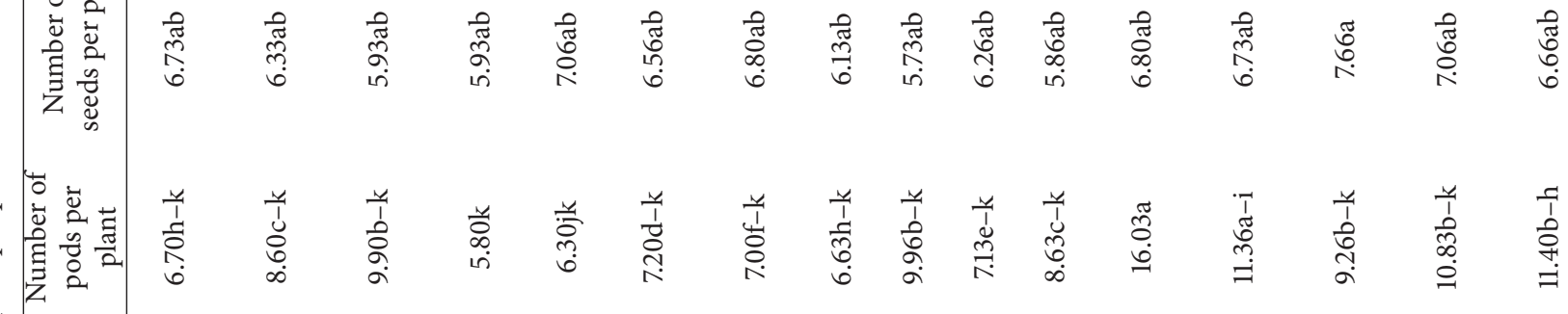

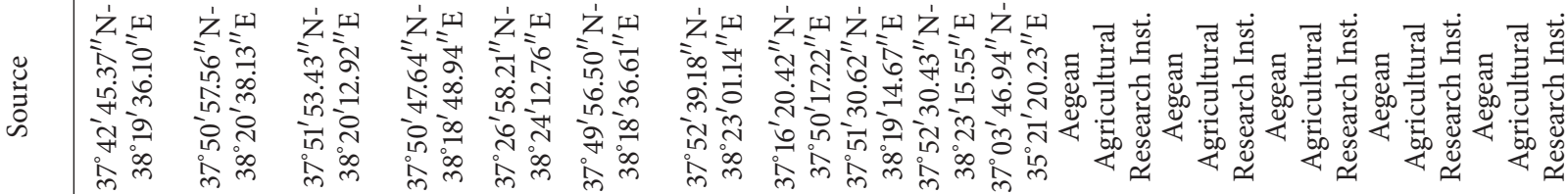

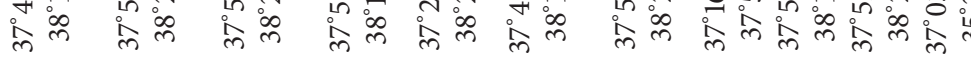

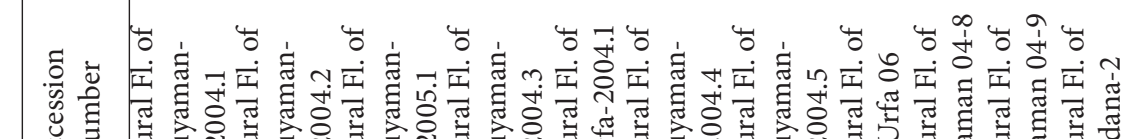

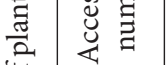

吾吾

敢安

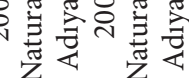

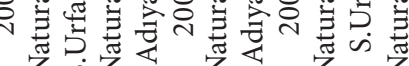

要窟

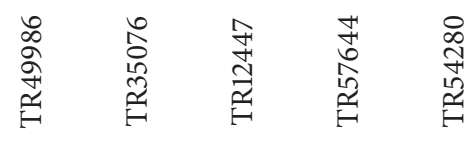

蒙

离

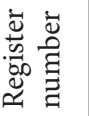

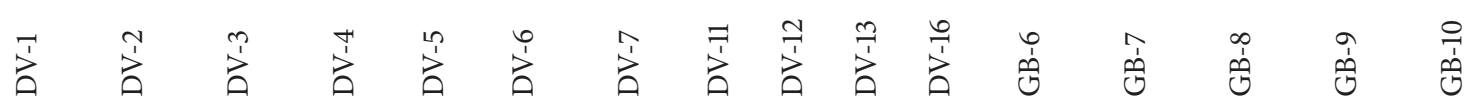




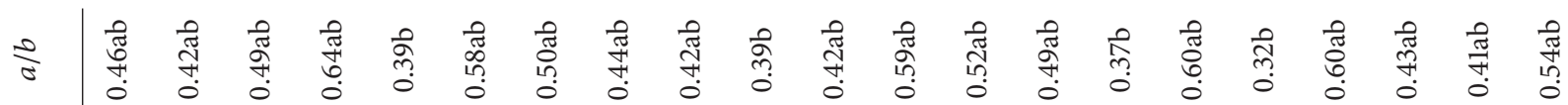

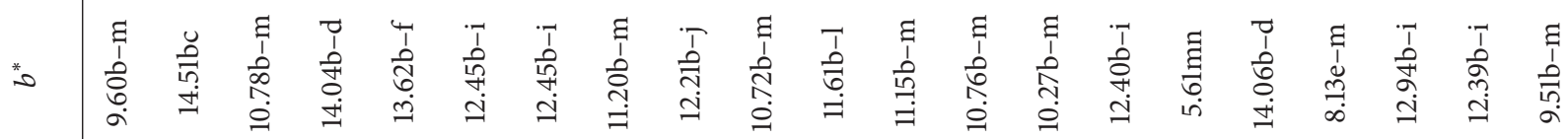

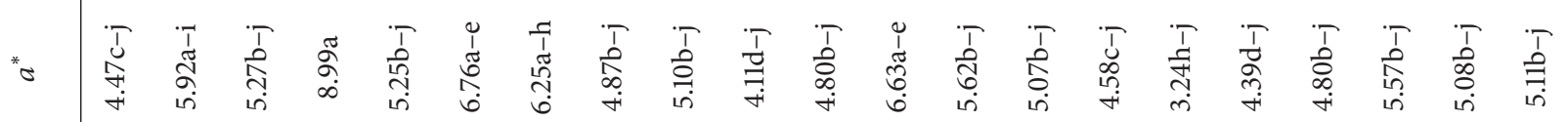

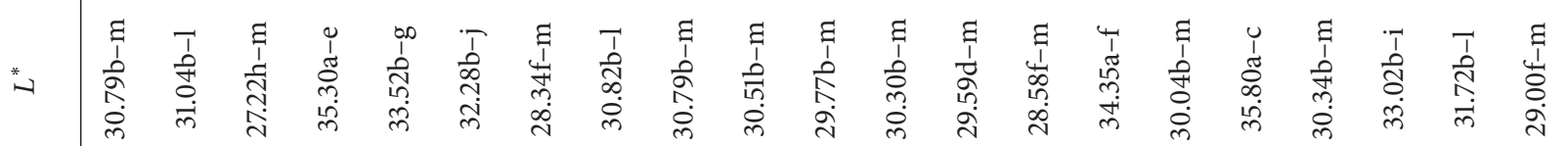

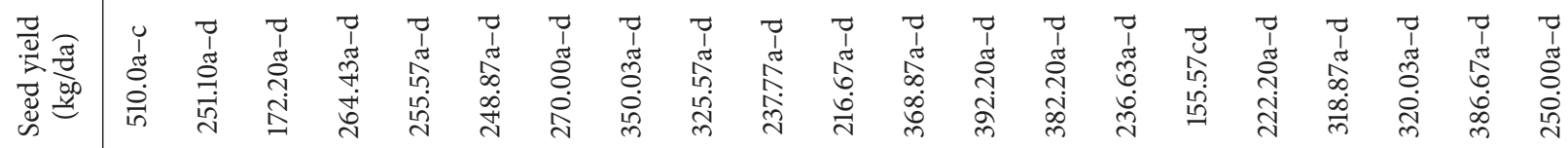

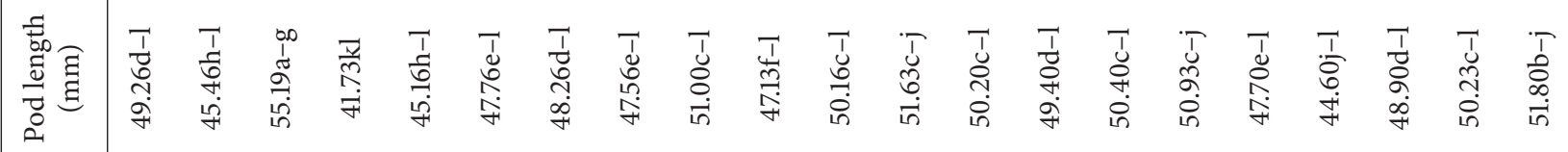

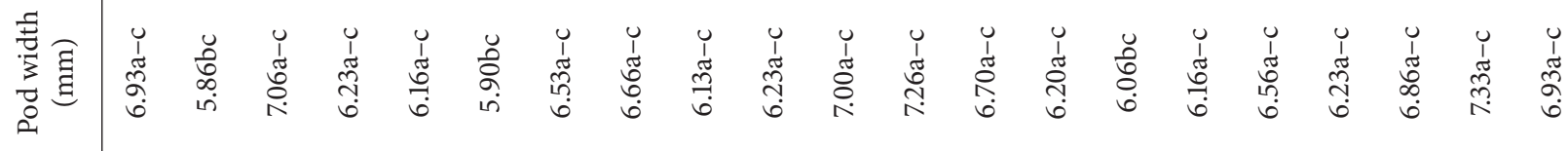

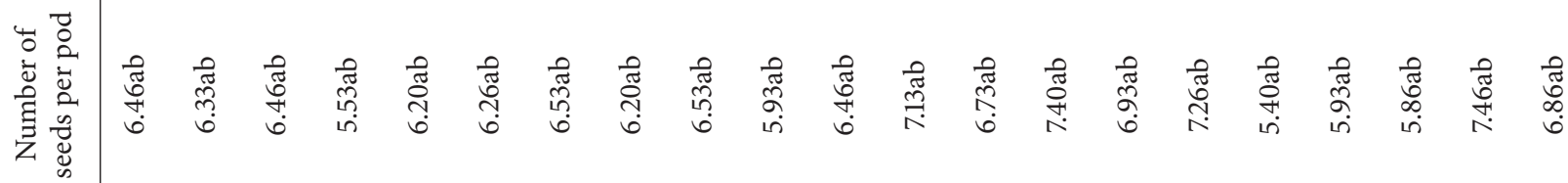

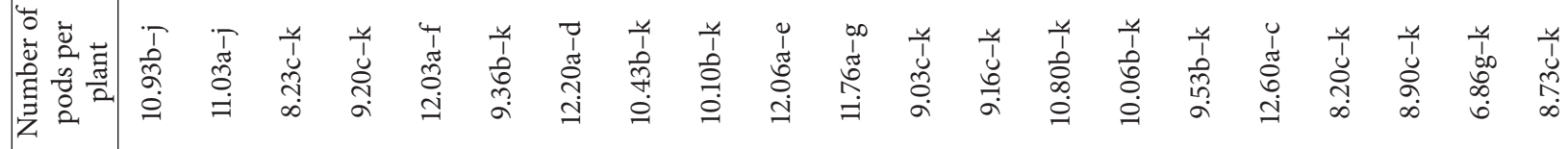

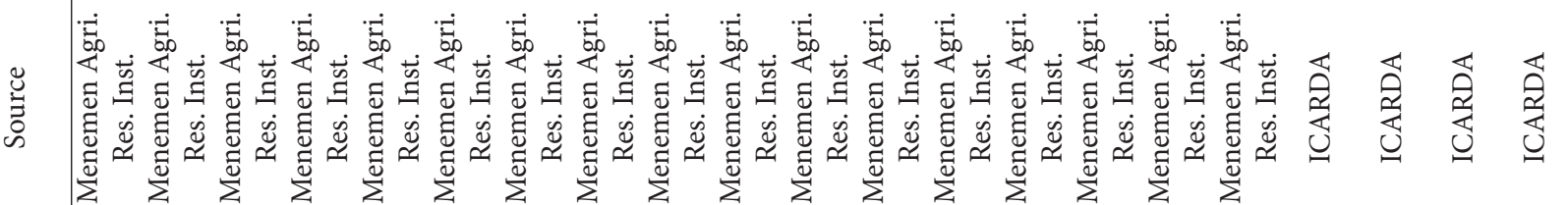

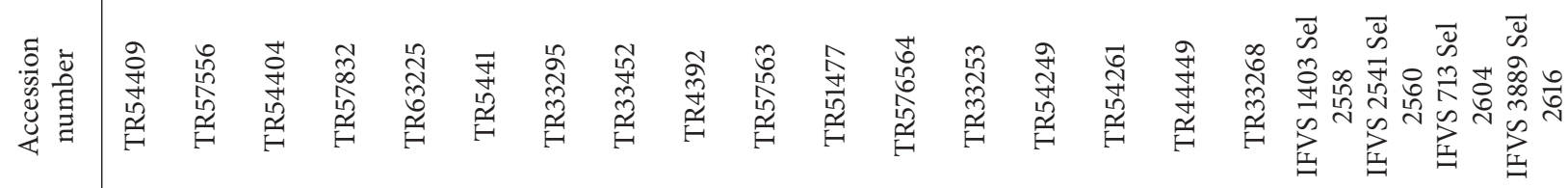

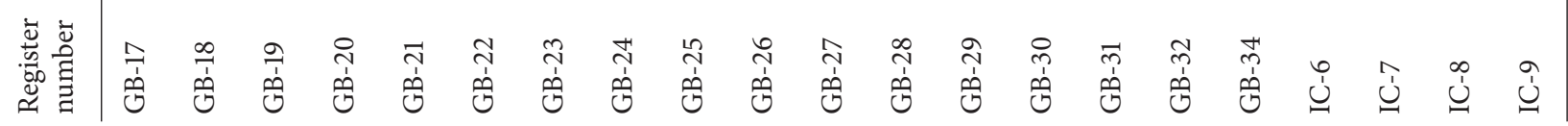




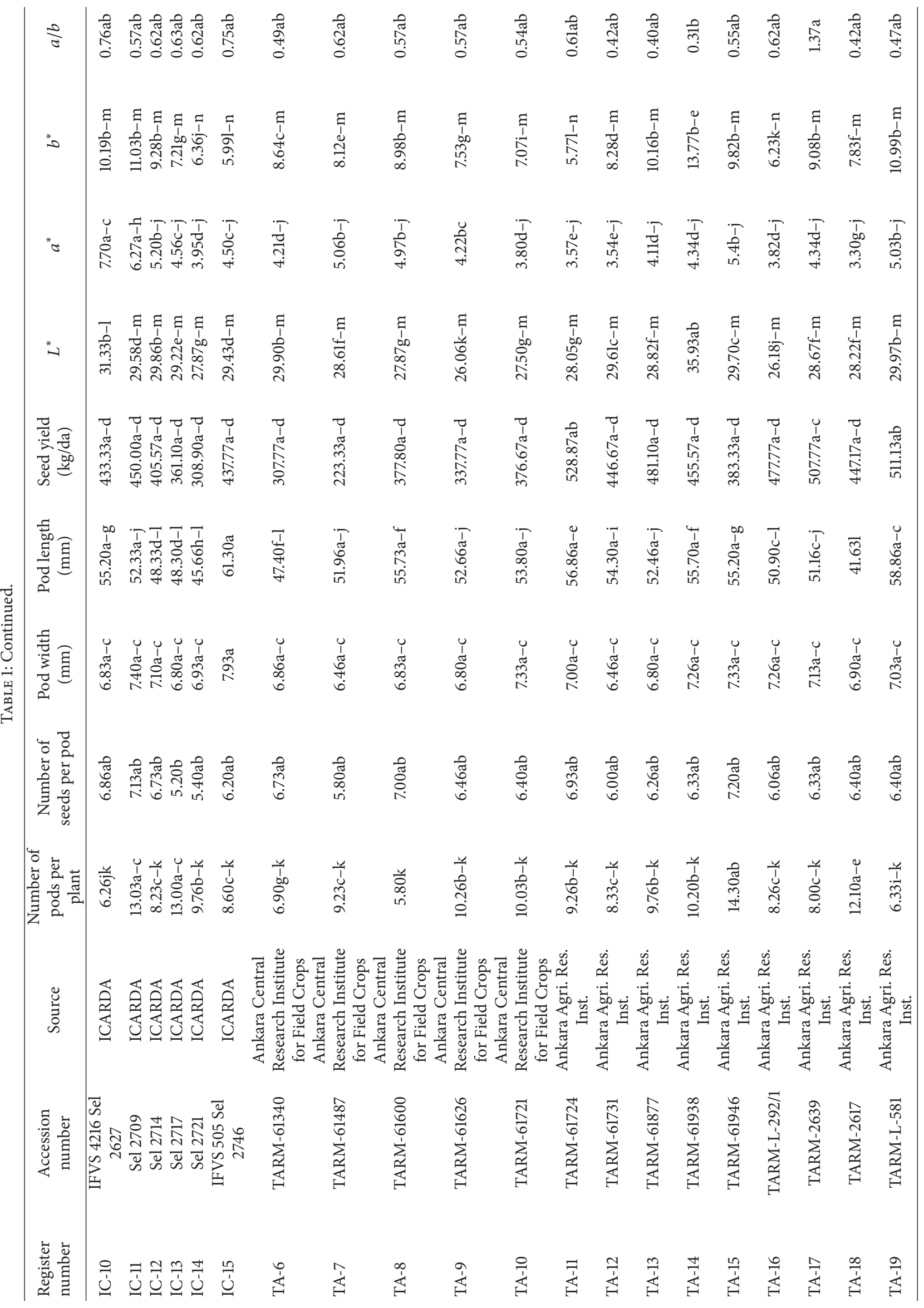




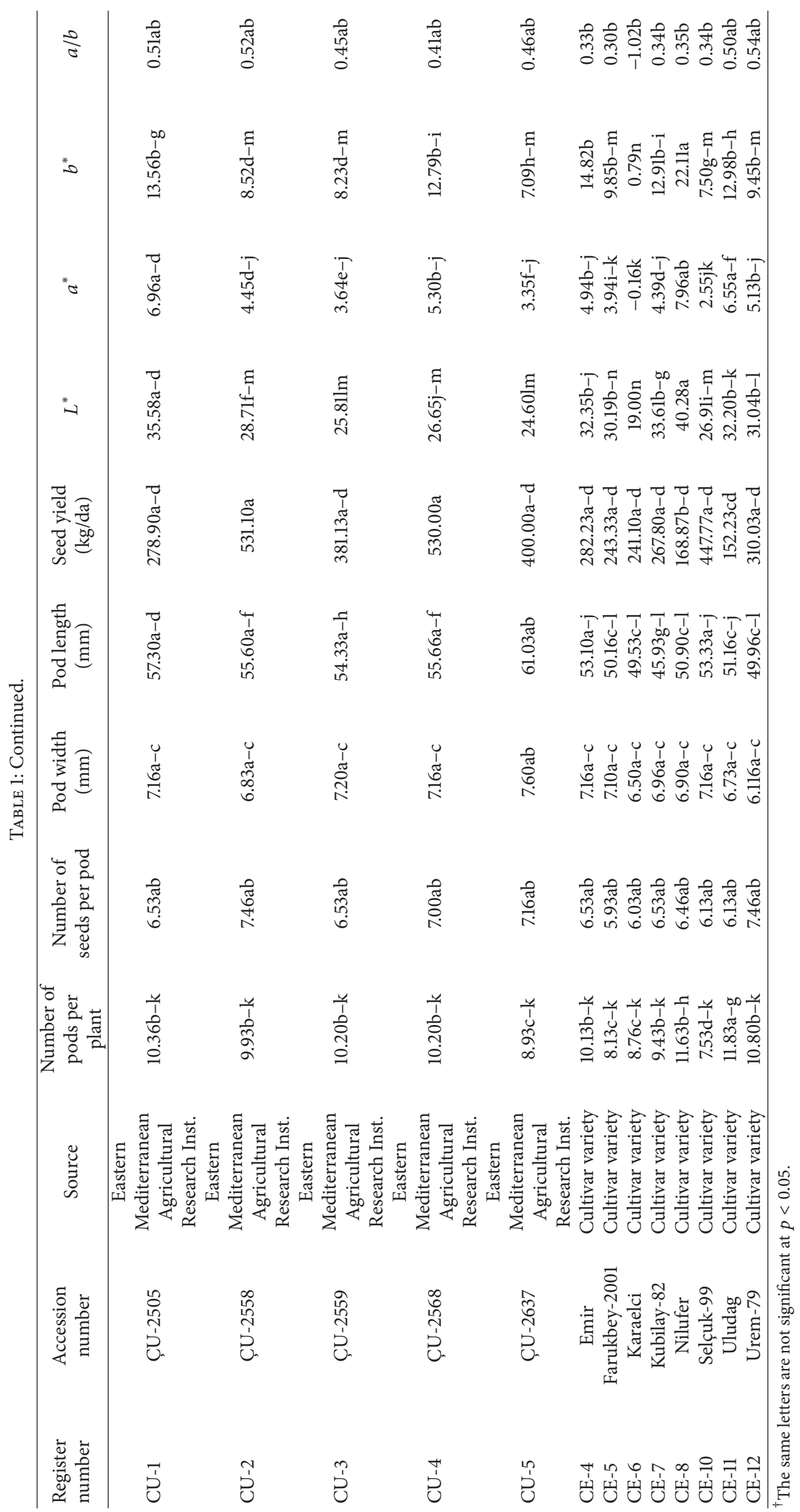


TABLE 2: Average minimum and maximum numbers of pods per plant, the number of seeds per pod, pod dimension (width and length), seed yield, and the colour parameters $\left(L^{*}, a^{*}\right.$, and $\left.b^{*}\right)$ of 70 common vetch lines and cultivars.

\begin{tabular}{|c|c|c|c|c|c|c|}
\hline Traits & $N$ & Mean & Std. Dev. & Sum & Minimum & Maximum \\
\hline Number of pods per plant & 210 & 9.56619 & 2.37260 & 2009 & 3.90 & 16.60 \\
\hline Number of seeds per pod & 210 & 6.48619 & 0.75897 & 1362 & 4.00 & 8.80 \\
\hline Pod width (mm) & 210 & 6.75238 & 0.61264 & 1418 & 5.00 & 9.00 \\
\hline Pod length (mm) & 210 & 50.64476 & 4.55112 & 10635 & 40.70 & 62.10 \\
\hline Seed yield $\left(\mathrm{kgda}^{-1}\right)$ & 210 & 322.55429 & 136.61476 & 67736 & 36.70 & 676.70 \\
\hline$L^{*}$ & 210 & 30.22248 & 3.38168 & 6347 & 18.73 & 41.57 \\
\hline$a^{*}$ & 210 & 5.06033 & 2.28750 & 1063 & -0.32 & 29.66 \\
\hline$b^{*}$ & 210 & 10.45290 & 3.25512 & 2195 & 0.11 & 23.60 \\
\hline$a / b$ & 210 & 0.48019 & 0.32553 & 100.84 & -2.91 & 3.15 \\
\hline
\end{tabular}

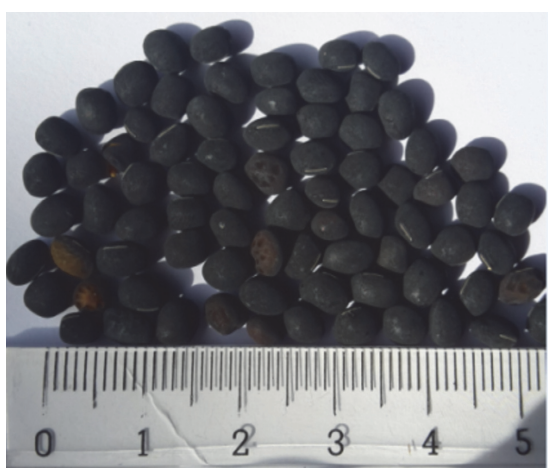

(a)

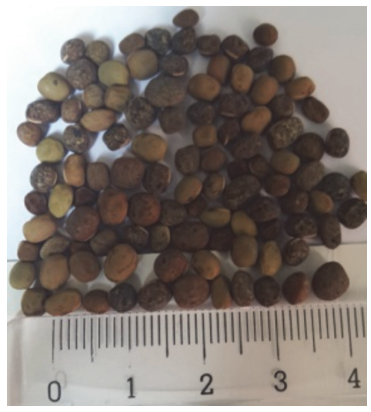

(d)

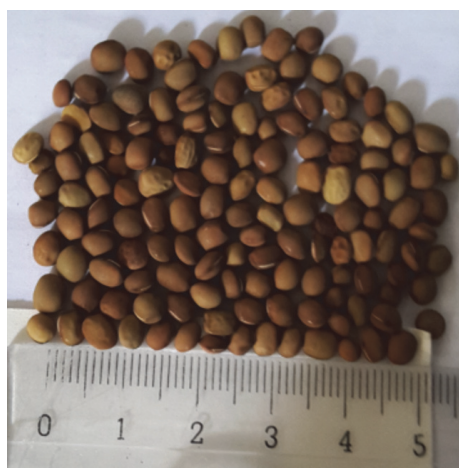

(b)

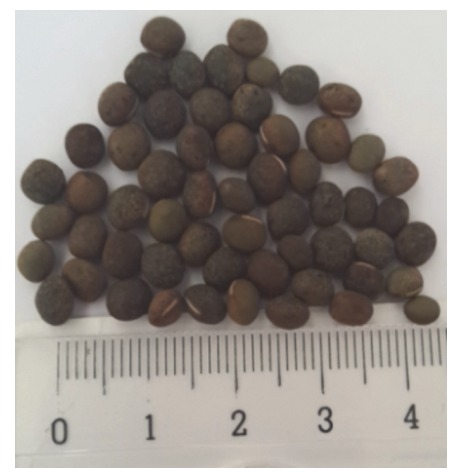

(c)

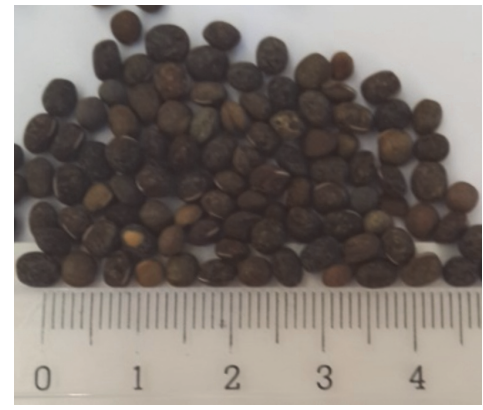

(e)

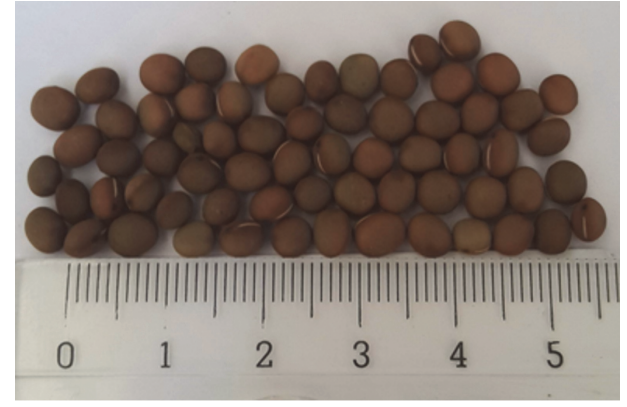

(f)

Figure 1: The appearance of the genotypes which distinctly differ from the others for seed coat colour. (a) Variety Karaelci, (b) variety Nilufer, (c) CU-2, (d) DV-1, (e) GB-6, and (f) GB-20.

of 62 lines and 8 cultivars was $30.22,5.06,10.45$, and 0.48 , respectively.

\subsection{Correlation between Seed Yield and Seed Coat Colour} Parameters. Statistically highly significant $(p<0.01)$ correlations were determined between the pod length and the number of seeds per pod, the pod length and pod width, seed yield and pod width, seed yield and pod length, $L^{*}$ and seed yield, $a^{*}$ and seed yield, $a^{*}$ and $L^{*}, b^{*}$ and seed yield, $L^{*}$ and $b^{*}, a^{*}$ and $b^{*}$, and $a^{*}$ and $a / b$ ratio (Table 3 ). Significant $(p<0.05)$ correlation coefficients were also determined between $L^{*}$ and pod width, $b^{*}$ and pod length, and $L^{*}$ and $a / b$ ratio. The highest correlation coefficients were determined between $b^{*}$ and $L^{*}(r=0.73)$ and $a^{*}$ and $L^{*}(r=$
0.55). In general, negative correlations between seed yield and coat colour parameters along with pod dimension were determined. For instance, yellowness $\left(b^{*}\right)$ and seed yield had correlation coefficient of -0.25 , while correlation between $L^{*}$ and seed yield was determined as -0.23 (Table 3 ).

\section{Discussion}

Seed coat structure and its colour are important traits for legume species not only to determine the quality and commercial values of seeds [21] but also to reveal seed germination parameters for agricultural applications [22]. Seed coat colour is also a central target in several plant species and any trait that is correlated to it may be a convenient way to 
TABLE 3: Pearson's correlation coefficient used to assess correlation among the seed coat colour and seed yield parameters of 70 common vetch lines and cultivars and related $p$ values.

\begin{tabular}{|c|c|c|c|c|c|c|c|c|c|}
\hline Traits & $\begin{array}{l}\text { Number of } \\
\text { pods per } \\
\text { plant }\end{array}$ & $\begin{array}{l}\text { Number of } \\
\text { seeds per pod }\end{array}$ & $\begin{array}{l}\text { Pod width } \\
\quad(\mathrm{mm})\end{array}$ & $\begin{array}{l}\text { Pod length } \\
\quad(\mathrm{mm})\end{array}$ & $\begin{array}{l}\text { seed yield } \\
\left(\mathrm{kgda}^{-1}\right)\end{array}$ & $L^{*}$ & $a^{*}$ & $b^{*}$ & $a / b$ \\
\hline $\begin{array}{l}\text { Number of pods per } \\
\text { plant }\end{array}$ & 1 & & & & & & & & \\
\hline \multirow{2}{*}{$\begin{array}{l}\text { Number of seeds per } \\
\text { pod }\end{array}$} & -0.04904 & 1 & & & & & & & \\
\hline & 0.4796 & & & & & & & & \\
\hline \multirow{2}{*}{ Pod width (mm) } & -0.11636 & 0.06485 & \multirow{2}{*}{1} & & & & & & \\
\hline & 0.0926 & 0.3497 & & & & & & & \\
\hline \multirow{2}{*}{ Pod length (mm) } & -0.17624 & 0.32087 & 0.48365 & \multirow{2}{*}{1} & & & & & \\
\hline & 0.0105 & $<0.0001$ & $<0.0001$ & & & & & & \\
\hline \multirow{2}{*}{ Seed yield $\left(\mathrm{kgda}^{-1}\right)$} & -0.05332 & 0.10199 & 0.19465 & 0.24161 & \multirow[t]{2}{*}{1} & & & & \\
\hline & 0.4422 & 0.1407 & 0.0046 & 0.0004 & & & & & \\
\hline \multirow{2}{*}{$L^{*}$} & 0.1012 & -0.0263 & -0.16435 & -0.13163 & -0.23014 & \multirow{2}{*}{1} & & & \\
\hline & 0.1439 & 0.7047 & 0.0171 & 0.0569 & 0.0008 & & & & \\
\hline \multirow{2}{*}{$a^{*}$} & 0.05322 & 0.04555 & -0.06789 & -0.06164 & -0.19073 & 0.55056 & \multirow{2}{*}{1} & & \\
\hline & 0.4429 & 0.5115 & 0.3275 & 0.3741 & 0.0056 & $<0.0001$ & & & \\
\hline \multirow{2}{*}{$b^{*}$} & 0.12978 & 0.01423 & -0.09391 & -0.14384 & -0.25423 & 0.73085 & 0.42699 & \multirow{2}{*}{1} & \\
\hline & 0.0605 & 0.8376 & 0.1752 & 0.0373 & $<0.0002$ & $<0.0001$ & $<0.0001$ & & \\
\hline \multirow{2}{*}{$a / b$} & -0.04814 & 0.03357 & 0.07596 & 0.02587 & 0.10186 & 0.13882 & 0.65761 & 0.03914 & \multirow{2}{*}{1} \\
\hline & 0.4878 & 0.6286 & 0.2732 & 0.7094 & 0.1413 & 0.0445 & $<0.0001$ & 0.5728 & \\
\hline
\end{tabular}

select/deselect desired/undesired plant material in a breeding program. Defining such correlation among coat colour and seed yield parameters of common vetch may help to improve better forage crops in common vetch breeding program. Such correlations were previously reported for other plant species such as sesame [9, 23], cowpea [24], and soybean [21]. Similarly, genotypes with reddish-brown seed coat of Brassica rapa showed higher oil content than that of yellowseeded genotypes [25]. Silique number and seed number per silique were positively correlated although a negative correlation was also reported between silique number and seed weight [25]. Seed coat thickness and seed colour are directly related to each other in B. rapa [26]. However, more recent study indicated that coat colour alone is not always a proper selection marker for meal digestibility since genotypes with very similar coat colour may show a large variation in seed acid detergent lignin [27]. On the other hand, the coat structure of Vicia sativa was found similar to other legumes and similar major seed coat characteristics were determined for both hard and soft lines of Vicia sativa [14]. It was also reported that the soft seeds are light brown in colour, while the hard seeds are black in common vetch [14]. The lowest values of coat colour data $\left(L^{*}, a^{*}, b^{*}\right.$, and $\left.a / b\right)$ obtained from variety Karaelci indicated that this variety distinctly differs from the others by having dull, blackness-blueness coat colour. The lightness and yellowness were the most on seeds of cultivar Nilufer, while the redness was pronounced more for line GB-20 in comparison to the other lines and cultivars tested. The negative correlations between seed yield and coat colour parameters along with pod dimension suggested that seed yield and pod dimensions decrease as the lightness, greenishness, and blueness of seed increase in common vetch. These findings also suggested that lightness and yellowness of seed coat may be used as important parameters to prescreen high yield genotypes of common vetch.

The pigmentation of the seed coat colour was mainly determined by flavonoids and anthocyanins [28]. It was reported that dark coat colour has higher concentration of anthocyanins and proanthocyanidins than lighter colour or white varieties of beans, offering a valuable source for antioxidants [29]. However, the external appearance of the coat colour is also influenced by environmental stimuli such as chilling stress or viral diseases [30] and environment can promote nongenetic maternal changes in the seed coat thickness and composition [31]. Such environmental stimuli mainly determine the final coat colour appearance of individual seed since flowering and seed maturation of many plants relatively take a long period of time in a distinct environmental condition. Previous reports indicated that the coat colour trait was polygenic controlled by several genes in various plant species including legumes such as cowpea $[24,32]$, bean [8], and soybean [21]. However, inheritance of coat colour of common vetch is controversial. Although some reports indicated that testa colour was governed by single gene with complete dominance [33, 34], others concluded that seed colour was a polymeric character $[35,36]$. Continuous colour variation determined by reflectance spectra in this study suggested that more than one gene might be involved in coat colour inheritance in common vetch rather than single gene with complete dominance. 
The results of this study also revealed significant variation among seed yield parameters and weak positive correlation coefficients between seed yield and pod width $(r=+0.19)$, seed yield, and pod length $(r=+0.24)$ were determined (Table 3 ). It was previously reported that harvest index, straw yield, spring vigor, and 1000-seed weight were important selection criteria for seed yield in common vetch [37], while pod dimensions and seed weight per plant have been identified as the major sources of diversity in Brassica seeds [38]. It was also shown that biomass and seed yield were strongly correlated to one another, while the relationship between seed yield and its components was not correlated with days to flowering in common vetch lines [19].

Seed coat structure and pigmentation also affect several germination parameters such as water uptake [9], persisting of coat imposed seed dormancy [10,39], and germination rate [11]. Previous reports showed that phenolic compounds and tight or loose adherence of the seed coat to the embryo influence rate of imbibition in legumes [40]. In addition, light coloured radicchio seeds were also shown to have reduced germination and as seed colour became darker, seeds had higher, faster, and more uniform germination [41]. Therefore, it might be interesting to determine how the coat colour influences germination and seedling emergence of common vetch under both normal and abiotic stress conditions. Seed quality parameters of common vetch based on the seed colour variation also await to be determined.

\section{Conclusions}

Evaluation of seed coat colour and seed yield parameters of 70 common vetch lines and cultivars revealed highly significant variation for those parameters measured. The highest correlation coefficients were determined between $b^{*}$ and $L^{*}(r=0.73)$ and $a^{*}$ and $L^{*}(r=0.55)$. Negative correlation coefficients determined between seed yield and coat colour yellowness $\left(b^{*}\right)(r=-0.25)$ and seed yield and seed coat lightness $(r=-0.23)$ suggested that such correlation may be used as an important tool for future common vetch breeding program.

\section{Competing Interests}

The authors have declared that no competing interests exist.

\section{Authors' Contributions}

Gulgun Yildiz Tiryaki performed seed coat colour experiment, interpreted related data, and drafted the manuscript. Abdullah Cil performed the field experiment. Iskender Tiryaki designed the experiments, analyzed the data, obtained the funding, and made critical revision of the manuscript.

\section{Acknowledgments}

A partial financial support was provided by The Scientific and Technological Research Council of Turkey (TUBITAK, TOVAG, Grant no. 107O012).

\section{References}

[1] R. Avcioglu, "Roughage feeding material production strategies in Turkey," in Proceedings of the International Animal Nutrition Congress, pp. 448-455, Isparta, Turkey, September 2000.

[2] F. C. Yeh, R. C. Yang, T. B. J. Boyle, Z. Ye, and J. K. Mao, Popgene, The User Friendly Shareware for Population Genetic Analysis, University of Alberta, Canada. Molecular Biology and Biotechnology Centre, 1997.

[3] M. Başbağ, H. Hoşgören, and A. Aydın, "Vicia taxan the flora of Turkey," Anadolu Journal of Agricultural Science, vol. 28, pp. 59-66, 2013.

[4] M. Frediani, P. Caputo, G. Venora, C. Ravalli, M. Ambrosio, and R. Cremonini, "Nuclear DNA contents, rDNAs, and karyotype evolution in Vicia subgenus Vicia: II. Section Peregrinae," Protoplasma, vol. 226, no. 3, pp. 181-190, 2005.

[5] N. Maxted, "An ecogeographical study of Vicia subgenus Vicia. Systematic and ecogeographic studies on crop genepools," in Proceedings of the International Plant Genetic Resources Institute (IPGRI '95), Rome, Italy, 1995.

[6] P. H. Davis, Flora of Turkey and the East Aegean Islands, Edinburgh University, Edinburgh, UK, 1970.

[7] D. Wang, F. E. Dowell, and R. E. Lacey, "Single wheat kernel size effects on near-infrared reflectance spectra and color classification," Cereal Chemistry, vol. 76, no. 1, pp. 34-37, 1999.

[8] M. T. D. F. Possobom, N. D. Ribeiro, A. E. M. Zemolin, and F. D. Arns, "Genetic control of the seed coat colour of Middle American and Andean bean seeds," Genetica, vol. 143, no. 1, pp. 45-54, 2015.

[9] F. H. D. de Souza and J. Marcos-Filho, "The seed coat as a modulator of seed-environment relationships in Fabaceae," Revista Brasileira de Botânica, vol. 24, no. 4, pp. 365-375, 2001.

[10] I. Tiryaki and M. Topu, "A novel method to overcome coatimposed seed dormancy in Lupinus albus L. and Trifolium pratense L.," Journal of Botany, vol. 2014, Article ID 647469, 6 pages, 2014.

[11] I. Debeaujon, K. M. Léon-Kloosterziel, and M. Koornneef, "Influence of the testa on seed dormancy, germination, and longevity in Arabidopsis," Plant Physiology, vol. 122, no. 2, pp. 403-413, 2000.

[12] A. A. Powell, "The importance of genetically determined seed coat characteristics to seed quality in grain legumes," Annals of Botany, vol. 63, no. 1, pp. 169-175, 1989.

[13] J. O. Ochuodho and A. T. Modi, "Dormancy of wild mustard (Sisymbrium capense) seeds is related to seed coat colour," Seed Science and Technology, vol. 36, no. 1, pp. 46-55, 2008.

[14] H. N. Büyükkartal, H. Çölgeçen, N. M. Pinar, and N. Erdoğan, "Seed coat ultrastructure of hard-seeded and soft-seeded varieties of Vicia sativa," Turkish Journal of Botany, vol. 37, no. 2, pp. 270-275, 2013.

[15] G. Hacisalihoglu and A. M. Settles, "Natural variation in seed composition of 91 common bean genotypes and their possible association with seed coat color," Journal of Plant Nutrition, vol. 36, no. 5, pp. 772-780, 2013.

[16] M. Marwanto, "Soybean seed coat characteristics and its quality losses during incubator aging and storage," Jurnal Ilmu-Ilmu Pertanian Indonesia, vol. 6, pp. 57-65, 2004.

[17] X. K. Zhang, J. Chen, L. Chen, H. Z. Wang, and J. N. Li, "Imbibition behavior and flooding tolerance of rapeseed seed (Brassica napus L.) with different testa color," Genetic Resources and Crop Evolution, vol. 55, no. 8, pp. 1175-1184, 2008. 
[18] W. Dana and W. Ivo, "Computer image analysis of seed shape and seed color for flax cultivar description," Computers and Electronics in Agriculture, vol. 61, no. 2, pp. 126-135, 2008.

[19] H. K. Firıncioğlu, S. Ünal, E. Erbektaş, and L. Doğruyol, "Relationships between seed yield and yield components in common vetch (Vicia sativa ssp. sativa) populations sown in spring and autumn in central Turkey," Field Crops Research, vol. 116, no. 1-2, pp. 30-37, 2010.

[20] SAS Institute, SAS/STAT Software: Changes and Enhancements Through Release 6.12, SAS Institute, Cary, NC, USA, 1997.

[21] K. Yang, N. Jeong, J.-K. Moon et al., "Genetic analysis of genes controlling natural variation of seed coat and flower colors in soybean," Journal of Heredity, vol. 101, no. 6, pp. 757-768, 2010.

[22] J. O. Ochuodho and A. T. Modi, "Association of seed coat colour with germination of three wild mustard species with agronomic potential," African Journal of Agricultural Research, vol. 8, pp. 4354-4359, 2013.

[23] H. Zhang, H. Miao, L. Wei, C. Li, R. Zhao, and C. Wang, "Genetic analysis and QTL mapping of seed coat color in sesame (Sesamum indicum L.)," PLoS ONE, vol. 8, no. 5, Article ID e63898, 2013.

[24] K. Egbadzor, M. Yeboah, D. Gamedoagba, S. Offei, E. Danquah, and K. Ofori, "Inheritance of seed coat colour in cowpea (Vigna unguiculata (L.) Walp)," International Journal of Plant Breeding and Genetics, vol. 8, no. 1, pp. 35-43, 2014.

[25] H. Bagheri, D. Pino-del-Carpio, C. Hanhart, G. Bonnema, J. Keurentjes, and M. G. M. Aarts, "Identification of seed-related QTL in Brassica rapa," Spanish Journal of Agricultural Research, vol. 11, no. 4, pp. 1085-1093, 2013.

[26] G. R. Stringam, D. I. Mcgregor, and S. H. Pawlowski, "Chemical and morphological characteristics associated with seed coat colour in rapeseed," in Proceedings of the 4th International Rapeseed Congress, pp. 99-108, Giessen, Germany, 1974.

[27] R. J. Snowdon, B. Wittkop, A. Rezaidad et al., "Regional association analysis delineates a sequenced chromosome region influencing antinutritive seed meal compounds in oilseed rape," Genome, vol. 53, no. 11, pp. 917-928, 2010.

[28] R. A. Dixon and L. W. Sumner, "Legume natural products: understanding and manipulating complex pathways for human and animal health," Plant Physiology, vol. 131, no. 3, pp. 878-885, 2003.

[29] L. G. Ranilla, M. I. Genovese, and F. M. Lajolo, "Polyphenols and antioxidant capacity of seed coat and cotyledon from Brazilian and Peruvian bean cultivars (Phaseolus vulgaris L.)," Journal of Agricultural and Food Chemistry, vol. 55, no. 1, pp. 90-98, 2007.

[30] M. Senda, C. Masuta, S. Ohnishi et al., "Patterning of virusinfected Glycine max seed coat is associated with suppression of endogenous silencing of chalcone synthase genes," Plant Cell, vol. 16, no. 4, pp. 807-818, 2004.

[31] E. P. Lacey, S. Smith, and A. L. Case, "Parental effects on seed mass: seed coat but not embryo/endosperm effects," American Journal of Botany, vol. 84, no. 11, pp. 1617-1620, 1997.

[32] Y. Mustapha, "Inheritance of seed coat colour pattern in cowpea [Vigna unguiculata (L.) Walp]," Bayero Journal of Pure and Applied Sciences, vol. 2, pp. 70-74, 2009.

[33] D. M. S. Chowdhury, J. M. Rathjen, M. E. Tate, and G. McDonald, "Genetics of colour traits in common vetch (Vicia sativa L.)," Euphytica, vol. 136, no. 3, pp. 249-255, 2004.

[34] M. Milczak, "A study of intervarietal hybrids of common vetch (Vicia sativa L.) II. Inheritance of some morphological features," Hodowla Roslin, Aklimatyzacja I Nasiennictwo, vol. 15, pp. 113$132,1971$.
[35] I. V. Yashovskii, E. S. Garmash, and I. V. Yashovsky, "Inheritance of seed colour in hybrids of Vicia sativa L. Genetika," USSR, vol. 14, no. 8, pp. 1423-1431, 1978.

[36] I. V. Prokofeva, "Inheritance of grain colour in spring vetch hybrids in crosses of the varieties typical and immaculate," Kratkie itogi raboty za1969 g. Mold. NII selektsii, semenovodstva I agrotekhn. Polev. Kul'tur., pp. 55-58, 1971.

[37] S. Çakmakçi, A. Ünay, E. Açikgöz, and S. Çakmakçı, "A study on the investigation of different methods related to seed and straw yields in common vetch (Vicia sativa L," Turkish Journal of Agriculture and Forestry, vol. 22, pp. 161-165, 1998.

[38] C. O. Sabanc1, "Evaluation of common vetch collections," Report of a Working Group on a Forages Sixth Meeting, IPGR, Rome, Italy, 1997.

[39] X. Li, J. M. Baskin, and C. C. Baskin, "Anatomy of two mechanisms of breaking physical dormancy by experimental treatments in seeds of two North American Rhus species (Anacardiaceae)," American Journal of Botany, vol. 86, no. 11, pp. 1505-1511, 1999.

[40] D. Chachalis and M. L. Smith, "Imbibition behavior of soybean (Glycine max (L.) Merrill) accessions with different testa characteristics," Seed Science and Technology, vol. 28, no. 2, pp. 321-331, 2000.

[41] F. Pimpin, M. F. Filippini, P. Sambo, and G. Gianquinto, "The effect of seed quality (seed colour variation) on storability, germination temperature and field performance of radicchio," Seed Science and Technology, vol. 30, no. 2, pp. 393-402, 2002. 


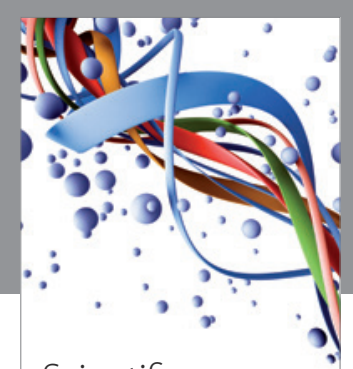

Scientifica
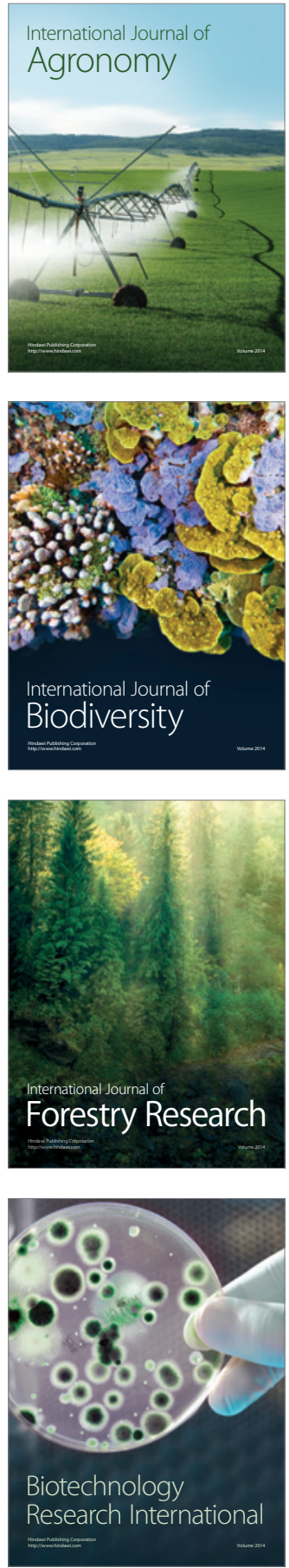
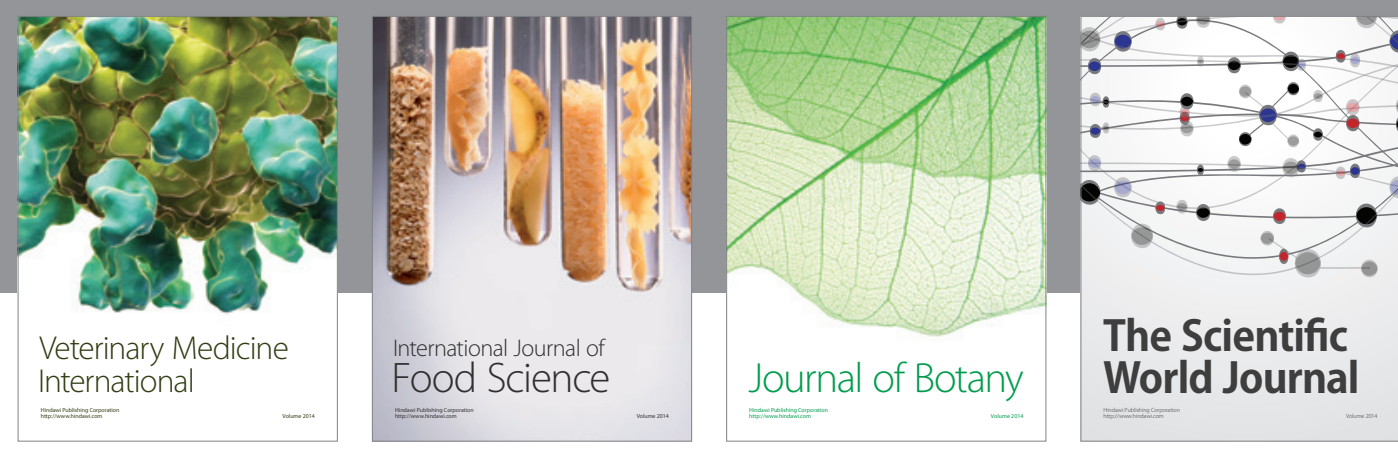

The Scientific

\section{World Journal}

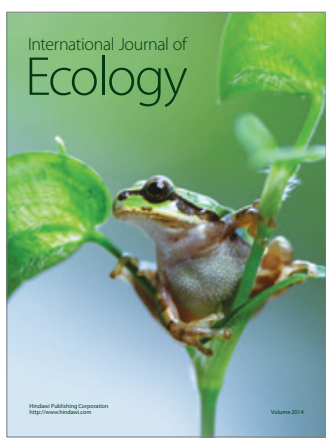

\section{Hindawi}

Submit your manuscripts at

http://www.hindawi.com
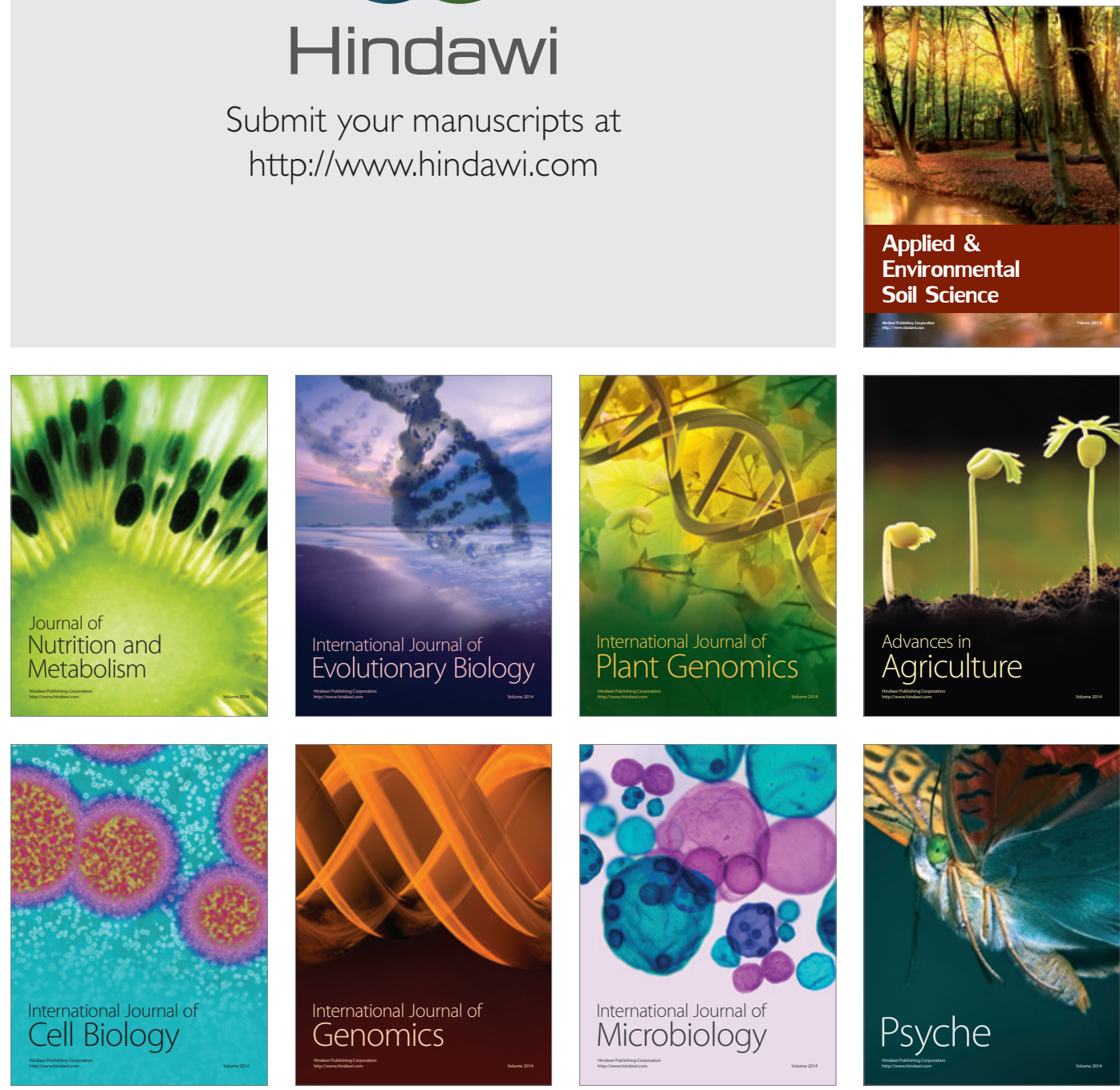
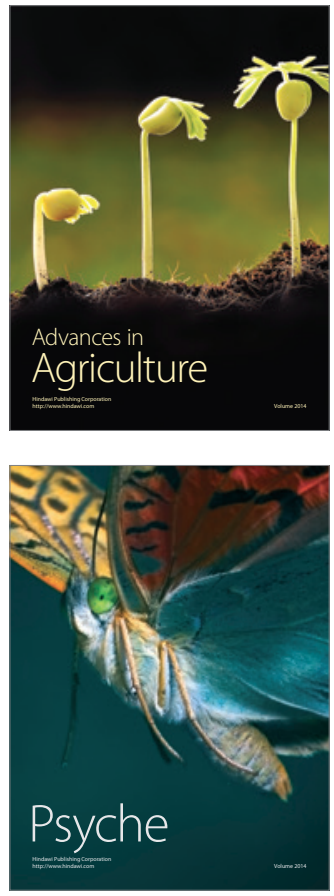